ЭТИОПАТОГЕНЕЗ СОЧЕТАННЫХ ПОРАЖЕНИЙ ЭНДОДОНТА И ПАРОДОНТА У ВЗРОСЛЫХ

DOI: $\frac{10.31618 / E S U .2413-9335.2019 .1 .67 .343}{\text { Мороз П. } \text { B. }^{1}}$

д.м.н., доиент, зав. кафедрой

Кафедра стоматологии №1

2. Ростов-на-Дону

Смирнова Ю.А. ${ }^{1}$

Ассистент кафедры стоматологии №1

Чистякова С.В. ${ }^{1}$

Ассистент кафедры стоматологии №1

Гуляева Е.Ш.

к.и.н., дочент Кафедры истории и культорологии

${ }^{1}$ «Ростовский государственный медицинский университет»

${ }^{2}$ Волгоградский государственный медицинский университет

\title{
COMBINED LESION OF ENDODONT AND PERIODONTAL IN ADULTS AND ITS CAUSES
}

\author{
P.V. Moroz ${ }^{I}$ \\ PhD, Associate Professor, Head the chair \\ Smirnova Y.A. ${ }^{1}$ \\ Assistant of the Department of Dentistry №1 \\ Chistyakova $S$. . $^{1}$ \\ Assistant of the Department of Dentistry №1 \\ Elena Sh. Gulyaeva ${ }^{2}$ \\ PhD in History, Professor Assistant \\ History and Culture Science Department \\ ${ }^{1}$ Department of Dentistry No. 1 \\ Rostov State Medical University, Ministry of Health of Russia \\ ${ }^{2}$ Volgograd State Medical University
}

\section{АННОТАЦИЯ}

Цель. До настоящего времени специалистами не изучены вопросы, связанные с формированием и прогрессированием эндодонто-пародонтальных поражений. Цель исследования - определить основные причины возникновения сочетанного поражения эндодонта и пародонта у взрослых людей.

Материал и методы. Проведено клиническое исследование 175 больных с хроническим периодонтитом и хроническим генерализованным пародонтитом. В группу сравнения были объединены 79 пациентов с хроническим генерализованным пародонтитом. Определены основные причины возникновения сочетанного поражения эндодонта и пародонта у взрослых людей с применением клинических параклинических, функциональных, включая изучение микроциркуляции пародонта, и статистических методов исследования.

Результаты. Установлены основные предрасполагающие факторы сочетанного поражения тканей эндодонта и пародонта, к которым следует отнести пародонтальные карманы глубиной более 5 мм, хронические периапикальные процессы зубов при выраженной воспалительной резорбции костной ткани, очаги которых относятся к гранулирующему периодонтиту, превышают в диаметре 7 мм и протекают фоне снижения гемомикроциркуляторного обеспечения тканей пародонта. Определены основные причины возникновения сочетанного поражения эндодонта и пародонта у взрослых людей, а также установлены основные предрасполагающие факторы сочетанного поражения тканей эндодонта и пародонта, что следует учитывать в клинической праткике врачей-стоматологов.

\section{ABSTRACT}

Relevance. To date, specialists have not studied issues related to the formation and progression of endodontoparodontal lesions. Purpose is to determine the main causes of combined lesions of endodont and periodontal in adults.

Material and methods. A clinical study was conducted on 175 patients with chronic periodontitis and chronic generalized periodontitis. In the comparison group, 79 patients with chronic generalized periodontitis were combined. The main causes of the occurrence of combined lesions of the endodont and periodontal in adults with the use of clinical paraclinical, functional, including the study of periodontal microcirculation, and statistical research methods are identified.

The results. The main predisposing factors of combined damage to endodontal and periodontal tissues have been established, to which periodontal pockets with a depth of more than $5 \mathrm{~mm}$ should be attributed, chronic periapical processes of the teeth with severe inflammatory resorption of bone tissue, the foci of which relate to granulating periodontitis, exceed $7 \mathrm{~mm}$ in diameter and are accompanied by a decrease in hemomicrocirculation. periodontal tissue. The main causes of the occurrence of combined endodontal and periodontal lesions in adults 
are identified, and the main predisposing factors of combined endodontal and periodontal tissue lesions are established, which should be taken into account in clinical practice of dentists.

Ключевые слова: эндодонтопародонтальные поражения, заболевания пародонта, пародонтит, заболевания эндодонта, хронический периодонтит, гемомикроциркуляция.

Key words: endodontoparodontal lesions, periodontal diseases, periodontitis, endodontal diseases, chronic periodontitis, hemomicrocirculation.

\section{Основные положения}

1. При эндодонто-пародонтальных поражениях наблюдается тотальная воспалительная резорбция костной ткани альвеолярных отростков (частей) челюстей при смешанном типе резорбции межзубных/межкорневых перегородок.

2. Основными предрасполагающими факторами сочетанного поражения тканей эндодонта и пародонта являются пародонтальные карманы глубиной более 5 мм, хронические периапикальные процессы зубов при выраженной воспалительной резорбции костной ткани, очаги которых относятся к гранулирующему периодонтиту, превышают в диаметре 7 мм и протекают фоне снижения гемомикроциркуляторного обеспечения тканей пародонта.

\section{Highlights}

1.With endodontoparodontal lesions, a total inflammatory resorption of the bone tissue of the alveolar processes (parts) of the jaws is observed with a mixed type of resorption of the interdental / interrooted partitions.

2.The main predisposing factors of combined damage of endodontal and periodontal tissues are periodontal pockets with a depth of more than $5 \mathrm{~mm}$, chronic periapical processes of teeth with severe inflammatory resorption of bone tissue, the foci of which relate to the granulating periodontitis, exceed 7 $\mathrm{mm}$ in diameter and flow against the background of a decrease in hemomicrocirculation supply of the tissues of the tissues that supply the body tissues. .

\section{Введение}

Сложный синдромокомплекс сочетанной патологии пародонта и эндодонта получил название эндодонто-пародонтального поражения (ЭПП) $[2,7,17]$. Долговременное сохранение зуба при такой патологии обычно маловероятно [4, 5, 19], стоматологи широко применяют удаление зуба как основную тактику лечения при ЭПП $[6,16]$, тем более, что ретроспективно сложно определить первичность развития патологии при ЭПП $[9,14]$.

В середине прошлого века за рубежом считалось, что в 50\% случаев у взрослых ЭПП являются причиной удаления зубов [8, 18]. В настоящее время вопросам клинической картины, диагностики, классификации и лечению пациентов, страдающих ЭПП, посвящены немногочисленные работы отечественных и зарубежных авторов $[1,3$, 13]. В литературе описана взаимосвязь патологии пульпы зуба и тканей пародонта, обусловленная эмбриональными, анатомическими

функциональными предпосылками для обмена инфекцией [2, 4]. Имеется ряд публикаций, рассматривающих этиопатогенетические особенности развития и прогрессирования ЭПП $[13,15]$. Делается акцент на близости микробного состава корневых каналов при патологии пульпы и микрофлоры пародонтальных карманов [7, 11]. Предложены классификации ЭПП, основанные на первичности развития поражения, этиологии, диагностике и прогнозе, а также тактике лечения ЭПП $[10,12,14]$. Однако до настоящего времени специалистами не изучен вопрос о частоте встречаемости ЭПП у взрослых людей, не уточнены многие вопросы, связанные с формированием и прогрессированием ЭПП, в том числе не изучены факторы риска возникновения ЭПП, что затрудняет разработку мер не только по профилактике возникновения ЭПП, но и по прогнозированию результата лечения и рецидивирования ЭПП у взрослых людей.

\section{ЦЕЛЬ ИССЛЕДОВАНИЯ}

Определить основные причины возникновения сочетанного поражения эндодонта и пародонта у взрослых людей.

\section{МАТЕРИАЛ И МЕТОДЫ ИССЛЕДОВАНИЯ}

Для реализации цели исследования проведено клиническое исследование на 112 (49 (43,7\%) женщин и 63 (56,3\%) мужчины) больных с хроническим периодонтитом и хроническим генерализованным пародонтитом (ХГП). В группу сравнения были объединены 50 (21 (42\%) женщина и 29 (58\%) мужчин) пациентов с ХГП средней и тяжелой степени тяжести, протекающим изолированно без поражения периодонта. Возраст больных в клинической группе варьировал в пределах 19-53 лет, в среднем - 45,2 $\pm 1,8$ лет. У лиц группы сравнения возраст составил от 18 до 57 лет, в среднем - 46,1 $\pm 1,8$ лет. Контрольная группа (здоровые доноры) состояла из 25 (9 (36\%) женщин и $16(64 \%)$ мужчин) человек от 20 до 50 лет, в среднем $-40,5 \pm 1,4$ лет.

При выявлении факторов риска возникновения ЭПП исходно у больных оценивали жалобы, анамнез жизни и болезни, уточняли особенности клинической манифестации воспалительного процесса, причины его обострения, проводили оценку стоматологического статуса по общепринятым пародонтологическим индексам. После рентгенологического обследования устанавливали исходный тип ЭПП с учетом соотношения типа хронического периодонтита по рентгенологической классификации, а также воспалительной резорбции костной ткани межзубных и (или) межкорневых перегородок альвеол челюстей и соотносили клиническую картину ЭПП с классом болезни по МКБ-10, в соответствии с классификацией ЭПП [16]. Также изучали динамику индекса кровоточивости десны, 
папиллярно-маргинально-альвеолярного индекса, индексов гигиены Silness-Loе и Федорова Ю. А. Володкиной В. В. (ИГФВ), рецессии десны, пародонтальных индексов Russel и Ramfjord, глубины пародонтальных карманов, выраженности патологической подвижности зубов по шкале Миллера, а также результаты плотности костных структур при лучевом исследовании. Среди необратимых пародонтальных индексов определяли индекс рецессии десны Stahl, Morris, a также индексы, измеряемые при рентгенологическом исследовании и характеризующие резорбцию костной ткани альвеолярного отростка: степень поражения фуркаций в горизонтальном направлении по Наmp, вертикальную убыль кости при фуркациях по Tarnow, Fletcher. У пациентов с ЭПП для оценки локального микроциркуляторного кровообращения и трофики пародонта, периапикальной области проводили визуальную компьютерную капилляроскопию и лазерную доплеровскую флоуметрию. Сравнительный анализ параметров микроциркуляторного русла у пациентов с ЭПП осуществляли в сравнении больными ХГП средней и тяжелой степени тяжести без поражения эндодонта и 25 здоровыми донорами без патологии пародонта.

Для изучения микроциркуляторного обеспечения периодонта использовали метод витальной компьютерной капилляроскопии. Исследования проводились в трех зонах десны: маргинальная десна, прикрепленная десна, переходная складка с помощью компьютерного капилляроскопа (КК 4-01 - «ЦАВ» ЗАО центр «Анализ веществ»). Кроме того, кровоток в десне определяли методом лазерной доплеровской флоуметрии (ЛДФ) с помощью анализатора ЛАКК02 (НПП «ЛАЗМА», г. Москва).

Взаимосвязи между разными показателями оценивали при помощи корреляционно- регрессионного анализа, метода построения таблиц сопряженности. Диагностическую ценность признаков определяли методом неоднородной последовательной процедуры путем вычисления диагностических коэффициентов и показателей информативности. Исследуемые показатели в настоящей работе для установления факторов риска возникновения ЭПП предоставлены в виде выборочного среднего значения и стандартной ошибки средней величины. Достоверность различий средних величин независимых выборок подвергали оценке при помощи параметрического критерия Стьюдента при нормальном законе распределения и непараметрического критерия Манна - Уитни при отличии от нормального распределения показателей. Проверку на нормальность распределения оценивали при помощи критерия Шапиро - Уилка. Для статистического сравнения долей с оценкой достоверности различий применяли критерий Пирсона $\chi^{2}$ с учетом поправки Мантеля - Хэнзеля на правдоподобие. Во всех процедурах статистического анализа считали достигнутый уровень значимости (p), критический уровень значимости при этом был равным 0,05.

\section{РЕЗУЛЬТАТЫ ИССЛЕДОВАНИЯ И ИХ} ОБСУЖДЕНИЕ

В ходе проведенного клинического, рентгенологического, функционального и статистического исследования вначале было определено состояние тканей пародонта у лиц клинической группы, а также показано, что чаще всего при ЭПП у пациентов наблюдалась тотальная воспалительная резорбция костной ткани альвеолярных отростков (частей) челюстей при смешанном типе резорбции межзубных/межкорневых перегородок.

\section{ПОКАЗАТЕЛИ СТОМАТОЛОГИЧЕСКОГО СТАТУСА ПРИ СОЧЕТАННОМ ПОРАЖЕНИИ ЭНДОДОНТА И ПАРОДОНТА}

Table 1

INDICATORS OF DENTAL STATUS IN COMBINED ENDODONTIC AND PERIODONTAL LESIONS $(M \pm M)$

\begin{tabular}{|c|c|}
\hline Показатель & $\mathrm{M} \pm \mathrm{m}$ \\
\hline Индекс зубного налета & $2,4 \pm 0,2$ \\
\hline Индекс зубного камня & $2,7 \pm 0,1$ \\
\hline Комбинированный гигиенический индекс & $2,6 \pm 0,2$ \\
\hline Индекс кровоточивости десны & $2,7 \pm 0,3$ \\
\hline Индекс рецессии десны, \% & $68,9 \pm 2,8$ \\
\hline Пародонтальный индекс Russel & $5,4 \pm 0,4$ \\
\hline Пародонтальный индекс Ramfjord & $5,0 \pm 0,2$ \\
\hline
\end{tabular}

Затем, при проведенном исследовании, было изучено влияние выраженности воспалительной резорбции костной ткани (остеодеструкции) в апикальном периодонте на активность воспалительных процессов в пародонте. Корреляционный анализ взаимосвязи показателя деструкции в апикальном периодонте и пародонтального индекса Рассела позволил выявить достоверную прямую зависимость: коэффициент корреляции составил $\mathrm{r}=0,57$ при $\mathrm{p}<$ 0,001. Линия регрессии зависимости между двумя показателями отличалась высоким градиентом подъема, что отражало прямую выраженную связь между признаками (рис. 1). 
Рис. 1. Линия регрессии, корреляционное поле точек с доверительным интервалом связи показателя деструкичи в апикальном периодонте и пародонтального индекса Рассела у больных с ЭПП

Fig. 1. The regression line, correlation field points with a confidence interval when the rate of distruction of the apical periodontium, and the periodontal index of Russell in patients with EPP

Наличие хронического гранулирующего периодонтита у больных ЭПП обычно сопровождалось повышением тяжести ХГП (табл.
2). У больных, страдающих хроническим гранулирующим периодонтитом, ХГП тяжелой степени тяжести наблюдался в 86,4\% случаев, а ХГП средней степени тяжести - в 13,6\%. Критерий Пирсона $\chi^{2}$, согласно величине которого оценивали сопряжение признаков, имел высокую величину $\chi^{2}$ $=68,6$ и доверительную вероятность $\mathrm{p}<0,001$, что подтверждало статистическую значимость влияния хронического гранулирующего периодонтита на тяжесть ХГП.

\section{СОПРЯЖЕНИЕ ТЯЖЕСТИ ХГП И НАЛИЧИЯ ХРОНИЧЕСКОГО ГРАНУЛИРУЮЩЕГО \\ СОПРЯЖЕНИЕ ТЯЖЕСТИ ХІП И НАЛИЧИЯ ХРОНИЧЕСКОГО ГРАНУЛИРУЮЩЕГО
ПЕРИООНТИТА У БОЛЬНЫХ ЭПП}

Таблица 2

CONJUGATION OF THE SEVERITY OF CGP AND THE PRESENCE OF CHRONIC GRANULATING PERIODONTITIS IN PATIENTS WITH EPP

\begin{tabular}{|c|c|c|c|}
\hline \multirow{2}{*}{ Тяжесть ХГП } & \multicolumn{2}{|c|}{ Хронический гранулирующий периодонтит } & Всего \\
\cline { 2 - 4 } & есть & нет & $6(5,4 \%)$ \\
\hline Легкая & 0 & $79(6,7 \%)$ & $82(73,2 \%)$ \\
\hline Средняя & $3(13,6 \%)$ & $5(5,5 \%)$ & $24(21,4 \%)$ \\
\hline Тяжелая & $19(86,4 \%)$ & $90(100 \%)$ & $112(100 \%)$ \\
\hline Всего & $22(100 \%)$ & 0,616 \\
\hline$\chi^{2}, \mathrm{p}$ & \multicolumn{3}{|c|}{$\chi^{2}=68,6, \mathrm{p}<0,001$} \\
\hline Коэффициент контингенции & \multicolumn{3}{|c|}{0} \\
\hline
\end{tabular}

Fig. 2

У больных ЭПП коэффициент контингенции или сопряжения между тяжестью ХГП и наличием хронического гранулирующего периодонтита имел высокое значение 0,616, что подчеркивало выраженность ассоциации двух признаков.

Наличие апикальной и боковой корневой кисты у больных ЭПС с меньшим влиянием $\left(\chi^{2}=\right.$ $12,3 ; \mathrm{p}=0,002)$ по сравнению с хроническим гранулирующим периодонтитом, но достоверно сказывалось на тяжести ЭПП. При наличии апикальной и боковой корневой кисты чаще встречалась средняя степень тяжести ХГП (табл. 3).

\section{СОПРЯЖЕНИЕ ТЯЖЕСТИ ХГП И НАЛИЧИЯ АПИКАЛЬНОЙ И БОКОВОЙ КОРНЕВОЙ КИСТЫ У БОЛЬНЫХ ЭПП}

\section{CONJUGATION OF SEVERITY OF CGP AND PRESENCE OF APICAL AND LATERAL ROOT} CYST IN PATIENTS WITH EPP

\begin{tabular}{|c|c|c|c|}
\hline \multirow{2}{*}{ Тяжесть ХГП } & Апикальная и боковая корневая киста & Всего \\
\cline { 2 - 4 } & есть & нет & $6(5,4 \%)$ \\
\hline Легкая & 0 & $39(9,4 \%)$ & $82(73,2 \%)$ \\
\hline Средняя & $43(89,6 \%)$ & $19(29,7 \%)$ & $24(21,4 \%)$ \\
\hline Тяжелая & $5(10,4 \%)$ & $64(100 \%)$ & $112(100 \%)$ \\
\hline Всего & $48(100 \%)$ & $\chi^{2}=12,3 ; \mathrm{p}=0,002$ & \\
\hline$\chi^{2}, \mathrm{p}$ & \multicolumn{3}{|c|}{0,315} \\
\hline Коэффициент контингенции
\end{tabular}

У больных ЭПП на тяжесть ХГП достоверно влиял размер остеодеструкции в апикальной периодонтальной области (табл. 4). С увеличением размеров деструкции апикального периодонта тяжесть ХГП повышалась. Коэффициент контингенции имел меньшее значение $(0,242)$ по сравнению с предыдущими факторами, но доверительная вероятность критерия согласия $\mathrm{p}=$ 0,031 свидетельствовала о том, что размеры деструкции апикального периодонта у больных ЭПП более 7 мм. Хоть и не определяли наличие ХГП тяжелой степени, но способствовали повышению тяжести течения воспалительных процессов в пародонте. 


\section{СОПРЯЖЕНИЕ ТЯЖЕСТИ ХГП И РАЗМЕРОВ ДЕСТРУКЦИИ АПИКАЛЬНОГО ПЕРИОДОНТА У БОЛЬНЫХ ЭПП}

Таблица 4

Table 4

PAIR OF GRAVITY PRESENT STUDY INCLUDED THE SIZE AND DESTRUCTION OF APICAL PERIODONTIUM IN PATIENTS WITH EPP

\begin{tabular}{|c|c|c|c|}
\hline \multirow{2}{*}{ Тяжесть ХГП } & Размеры деструкции апикального периодонта & Всего \\
\cline { 2 - 4 } & $<7$ мм & $\geq 7$ мм & $6(5,4 \%)$ \\
\hline Легкая & $5(13,2 \%)$ & $1(1,4 \%)$ & $82(73,2 \%)$ \\
\hline Средняя & $26(68,4 \%)$ & $56(75,7 \%)$ & $24(21,4 \%)$ \\
\hline Тяжелая & $7(18,4 \%)$ & $17(22,9 \%)$ & $112(100 \%)$ \\
\hline Всего & $38(100 \%)$ & $74(100 \%)$ & 0,242 \\
\hline$\chi^{2}, \mathrm{p}$ & \multicolumn{3}{|c|}{$\chi^{2}=6,96 ; \mathrm{p}=0,031$} \\
\hline Коэффициент контингенции & \multicolumn{3}{|c|}{0,242} \\
\hline
\end{tabular}

Наибольшее влияние на тяжесть ХГП у больных ЭПП оказывал фактор наличия верхушечного гранулирующего периодонтита.

Учитывая наличие очевидной патогенетической значимости нарушений микроциркуляции периодонта для течения ЭПП [1, 2, 18], нами был проведtн сравнительный анализ параметров микроциркуляторного русла у пациентов с ЭПП, а также у больных ХГП средней и тяжелой степени тяжести без поражения эндодонта и здоровых доноров без патологии пародонта. Диаметр капилляров в периапикальных тканях пародонта у больных с ЭПП, ХГП и у здоровых доноров измеряли в артериальном, венозном и переходном отделах микроциркуляторного русла (рис. 2). В артериальном отделе капилляры, как у больных клинической группы, так и группы сравнения, были у́же $(\mathrm{p}<0,05)$ контрольных значений здоровых доноров, соответственно на 13\% и $11 \%$. Между пациентами с ЭПП и больными с ХГП без поражения эндодонта статистически значимых различий диаметра артериол не наблюдалось. В венозном отделе у пациентов клинической группы и группы сравнения капилляры, напротив, были расширены $(\mathrm{p}<0,05)$ по сравнению с контрольными величинами, соответственно на $32 \%$ и 24\%. При ЭПП в периапикальных тканях пародонта микрососуды венозного отдела были достоверно шире $(\mathrm{p}<0,05)$ по сравнению с больными при ХГП на 6\%, хотя расширение было незначительным. У больных клинической группы по мере утяжеления степени ХГП в периапикальных областях диаметр капилляров в артериальном и венозном отделах имел наибольшую величину при средней степени тяжести, а наименьшую - при тяжелой степени поражения пародонта. В переходном отделе у больных ЭПП происходило последовательное снижение диаметра капилляров от легкой к средней и тяжелой степени ХГП. У пациентов клинической группы при ХГП средней степени диаметр капилляров как в артериальном, так и в венозном отделах был шире $(\mathrm{p}<0,05)$ по сравнению с группой сравнения, соответственно, на $8 \%$ и 10\% (табл. 5).

Рис. 2. Результаты капилляроскопии пародонта без патологии у здорового донора (a), при средней тяжести течения ХГП (б), при ЭПП и ХГП средней тяжести (в), при ЭПП и ХГП тяжелой степени тяжести (2)

Fig. 2. The results of capillaroscopy without periodontal pathology in a healthy donor (a) with average severity present study included (b), with EPP and the present study included the average severity

(b), if EPP and the present study included severe degree of gravity $(g)$ ПЕРИАПКАЛЬНЫХ ТКАНЯХ ПАРОДОНТА У БОЛЬНЫХ С ЭПП, ХГП И ЗДОРОВЫХ ДОНОРОВ (МКМ)

Table 5

THE DIAMETER OF THE CAPILLARIES IN THE ARTERIAL, VENOUS AND TRANSITIONAL DIVISION IN THE PERIAPICAL PERIODONTAL TISSUES IN PATIENTS WITH EPP, THE PRESENT STUDY INCLUDED HEALTHY DONORS $(\boldsymbol{\mu M})$

\begin{tabular}{|c|c|c|c|}
\hline \multirow{2}{*}{ Группа исследования } & \multicolumn{3}{|c|}{ D капилляров, мкм } \\
\cline { 2 - 4 } & Артериальный отдел & Венозный отдел & Переходный отдел \\
\hline Клиническая (ЭПП), $\mathrm{n}=112$ & $6,1 \pm 0,3$ & $12,5 \pm 0,2$ & $8,8 \pm 0,3$ \\
\hline Группа сравнения (ХГП), $\mathrm{n=50}$ & $6,2 \pm 0,2$ & $11,8 \pm 0,1$ & $9,6 \pm 0,2$ \\
\hline Здоровые доноры, $\mathrm{n}=25$ & $7,0 \pm 0,4$ & $9,5 \pm 0,3$ & $11,2 \pm 0,4$ \\
\hline \multirow{2}{*}{$\mathrm{p}$} & $\mathrm{p}^{1}<0,05$ & $\mathrm{p}^{1}<0,001$ & $\mathrm{p}^{1}<0,05$ \\
& $\mathrm{p}^{2}<0,05$ & $\mathrm{p}^{2}<0,001$ & $\mathrm{p}^{2}<0,05$ \\
& $\mathrm{p}^{3}>0,05$ & $\mathrm{p}^{3}<0,05$ & $\mathrm{p}^{3}<0,05$ \\
\hline
\end{tabular}

$p^{1}$ - доверительная вероятность различий показателей клинической группь и здоровых доноров, $p^{2}$ - доверительная вероятность различий показателей группь сравнения и здоровых доноров, 
$p^{3}$ - доверительная вероятность различий показателей клинической группы и группы сравнения

Note: $\mathrm{p} 1$ - confidence level of differences of indicators of clinical groups and healthy donors,

p 2 - confidence level of differences in the indicators of the comparison group and healthy donors,

p 3 - the confidence of differences of indicators of the clinical group and the comparison group

При тяжелой степени ХГП у больных с ЭПП по сравнению с группой сравнения диаметр капилляров в артериальном и переходном отделах был уже на $10 \%$ и $13 \%$, а в венозном отделе - шире на $20 \%$, соответственно.

Плотность капиллярной сети представляет собой относительную величину, рассчитываемую как количество капилляров, приходящихся на единицу площади исследуемого объекта. В нашей работе за единицу площади принимали мкм². Перфузионный баланс представлял собой разность объемных скоростей капиллярного кровотока в артериальном и венозном отделах капилляра и характеризовал направление потока крови в капилляре «кровь-ткань», то есть определяет состояние транскапиллярного обмена. Плотность капиллярной сети у больных клинической группы была ниже по сравнению с группой сравнения и контролем, соответственно на $27,8 \%(\mathrm{p}<0,001)$ и 64,9\% (p < 0,001). В двух группах больных утяжеление поражения пародонта сопрягалось со снижением плотности капиллярной сети. По результатам лазерной доплеровской флоуметрии уровень перфузии тканей пародонта в периапикальной области у больных клинической группы был снижен по сравнению со здоровыми донорами на $27 \%(\mathrm{p}<0,05)$, а у пациентов группы сравнения - на $14 \%(\mathrm{p}<0,05)$. У пациентов с ЭПП по мере утяжеления ХГП показатель микроциркуляции изменялся разнонаправленно: при ХГП средней степени тяжести интенсивность капиллярного кровотока возрастала (на $80 \%$ (р < $0,01)$ по сравнению с легкой степенью тяжести ХГП), при тяжелой степени ХГП резко снижалась (на $34 \%(\mathrm{p}<0,05)$ по сравнению с легкой и на $63 \%$ ( $<<0,001)$ по сравнению со средней степенью тяжести ХГП). В группе сравнения при тяжелой степени тяжести ХГП по сравнению со среднетяжелым течением ХГП интенсивность кровотока также резко снижалась. При средней степени тяжести ХГП наблюдалась гиперемия, которая в большей мере была выражена в группе сравнения. Напротив, ограничение кровотока при тяжелом ХГП было выражено в большей мере при ЭПП. Снижение среднеквадратичного отклонения амплитуды колебаний показателя микроциркуляции и коэффициента вариации у больных двух групп подтверждало наличие застойных явлений в микроциркуляторном русле пародонта, снижение вазомоторной активности микрососудов, что свидетельствует о значительных застойных явлениях в капиллярах. Причем застойные явления в капиллярах были выявлены в большей мере при сочетанном поражении эндодонта и пародонта.

Анализ совокупностей микроциркуляторных изменений в периапикальной области свидетельствовал об ограничении микроциркуляторного обеспечения и перфузии тканей пародонта в группах больных, более выраженных при ЭПП, что может приводить к нарушению тканевого гомеостаза, саморегуляции метаболических процессов в пародонте, усугублению патологических воспалительных процессов. При этом ограниченное микроциркуляторное обеспечение может приводить к снижению устойчивости к инфицированию и регенеративной способности, а также негативно влиять на результативность проводимых лечебных мероприятий при ЭПП. Это, очевидно, необходимо учитывать не только как фактор возникновения ЭПП при сочетании патологии эндодонта и пародонта, но и при планировании лечебно-профилактических мероприятий при ЭПП, а также при ХГП.

\section{Заключение}

В ходе клинико-рентгенологического, функционального и статистического исследования установлены основные предрасполагающие факторы сочетанного поражения тканей эндодонта и пародонта, к которым следует отнести пародонтальные карманы глубиной более 5 мм, хронические периапикальные процессы зубов при выраженной воспалительной резорбции костной ткани, очаги которых относятся к гранулирующему периодонтиту, превышают в диаметре 7 мм и протекают фоне снижения гемомикроциркуляторного обеспечения тканей пародонта.

\section{СПИСОК ИСПОЛЬЗОВАННОЙ ЛИТЕРАТУРЫ/REFERENCES}

Галеева 3. Р. Морфофункциональные и этиопатогенетические связи при патологии эндодонта и пародонта // Эндодонтия today. 2012. № 2. C. 3-7.

Galeyeva Z. R. Morphofunctional and etiopathogenetic relationships in the pathology of endodont and periodontal // Endodontiya today. 2012. № 2. P. 3-7.

Грудянов А. И., Макеева М. К. Частота встречаемости эндодонто-пародонтальных поражений и информированность врачей об особенностях их диагностики и лечения // Стоматология. 2014. Т. 93. №3. С. 11-14.

Grudyanov A. I., Makeyeva M. K. The frequency of occurrence of endodonto-periodontal lesions and the awareness of doctors about the features of their diagnosis and treatment // Stomatologiya. 2014. T. 93. №3. P. 11-14.

Иорданишвили А. К., Мороз П. В. Эндодонтопародонтальные поражения у взрослых // Вестн. Рос. воен.-мед. акад. 2017. №1 (57). С. 2427. 
Iordanishvili A. K., Moroz P. V. Endodontoparodontal lesions in adults // Vestn. Ros. voyen.-med. akad. 2017. №1 (57). P. 24-27.

Иорданишвили А. К., Мороз П. В., Перемышленко А. С. и др. Пульпа зуба и патология пародонта: клинико-морфологические параллели // Уральский мед. журн. 2017. №8. С. 4-7.

Iordanishvili A. K., Moroz P. V., Peremyshlenko A. S. i dr. Tooth pulp and periodontal pathology: clinical and morphological parallels // Ural'skiy med. zhurn. 2017. №8. P. 4-7.

Иорданишвили А. К., Музыкин М. И., Какурников И. А., Рыжак Г. А. Возрастные изменения верхушки корня зуба у взрослого человека // Эндодонтия today. 2017. №4. С. 33-35.

Iordanishvili A. K., Muzykin M. I., Kakurnikov I. A., Ryzhak G. A. Age-related changes in the apex of the tooth root in an adult // Endodontiya today. 2017. №4. P. 33-35.

Каршиев Х. К., Робустова Т. Г., Музыкин М. И., Иорданишвили А. К. Оценка степени тяжести течения осложнённых форм острой одонтогенной инфекции // Вестн. Рос. воен.-мед. акад. 2017. №4 (60). C. 67-71.

Karshiyev Kh. K., Robustova T. G., Muzykin M. I., Iordanishvili A.K. Estimation of severity of complicated forms of acute odontogenic infection // Vestn. Ros. voyen.-med. akad. 2017. №4 (60). S. 67 71.

Комаров Ф. И., Шевченко Ю. Л., Иорданишвили А. К. Соматическое и стоматологическое здоровье долгожителей // Экология и развитие общества. 2016. №1 (16). С. 51-54.

Komarov F. I., Shevchenko Yu. L., Iordanishvili A. K. Somatic and dental health of long-livers // Ekologiya i razvitiye obshchestva. 2016. №1 (16). P. 51-54.

Комаров Ф. И., Шевченко Ю. Л., Иорданишвили А. К. Долгожительство: ремарки к патологии зубов и пародонта // Пародонтология. 2017. №2. C. 13-15.

Komarov F. I., Shevchenko Yu. L., Iordanishvili A. K. Longevity: remarks to the pathology of the teeth and periodontal // Parodontologiya. 2017. №2. P. 1315.

Митронин А. В. Аспекты лечения верхушечного периодонтита у пациентов старших возрастных групп // Эндодонтия today. 2004. №1-2. C. 33-35.

Mitronin A. V. Aspects of treatment of apical periodontitis in patients of older age groups // Endodontiya today. 2004. №1-2. P. 33-35.

Митронин А. В., Попова В. М., Дашкова О. П. и др. Отдаленные результаты эндодонтического лечения при эндодонто-пародонтальных поражениях /Эндодонтия today. 2017. №2. С. 37-40.

Mitronin A. V., Popova V. M., Dashkova O. P. i dr. Dashkova O. P. and others. Long-term results of endodontic treatment for endodonto-periodontal lesions // Endodontiya today. 2017. №2. P. 37-40.

Мороз П. В., Орехова Л. Ю., Ломова А. С. Отличительные пародонтологического статуса больных при эндопародонтальном синдроме // Пародонтология. 2015. T. 20. №4 (77). C. 53-58.

Moroz P. V., Orekhova L. Yu., Lomov A. S. Distinctive features of the periodontal status of patients with endoparodontal syndrome // Parodontologiya. 2015. T. 20. №4 (77). P. 53-58.

Мороз П. В., Атаева С. В., Биркина Ю. А. Стратегия лечения больных с эндодонтопародонтальными поражениями с применением направленной тканевой регенерации // Здоровье и образование в XXI веке. 2017. Т. 19. №8. С. 27-31.

Moroz P. V., Atayeva S.V., Birkina YU.A. The treatment strategy for patients with endodontoperiodontal lesions using targeted tissue regeneration // Zdorov'ye i obrazovaniye v XXI veke. 2017. T. 19. №8. P. 27-31.

Мороз П. В., Иорданишвили А. К., Проходная В. А. и др. Особенности клиническлого течения и принципы лечения эндодонто-пародонтальных поражений // Казанский мед. журн. 2018. Т. 99. №3. C. 362-368.

Moroz P. V., Iordanishvili A. K., Prokhodnaya V. A. i dr. Clinical course features and principles of treatment of endodonto-periodontal lesions // Kazanskiy med. zhurn. 2018. T. 99. №3. Р. 362-368.

Мороз П. В., Иорданишвили А. К., Перепелкин А. И. Закономерности формирования и особенности клинического течения эндодонтопародонтальных поражений у взрослых // Пародонтология. 2018. Т. 23. №2 (87). С. 76-80.

Moroz P. V., Iordanishvili A. K., Perepelkin A. I. Patterns of formation and features of the clinical course of endodonto-periodontal lesions in adults // Parodontologiya. 2018. T. 23. №2 (87). P. 76-80.

Мороз П. В., Иорданишвили А. К. Факторы риска возникновения и причины низкой эффективности лечения эндодонтопародонтальных поражений // Эндодонтия today. 2018. №1. С. 35-41.

Moroz P. V., Iordanishvili A. K. Risk factors for the occurrence and causes of low effectiveness of treatment of endodontoparodontal lesions // Endodontiya today. 2018. №1. S. 35-41.

Иорданишвили А. К., Мороз П. В. Эндодонтопародонтальные поражения жевательного аппарата и их лечение: учебное пособие. - СПб.: Изд-во «Человек», 2017. - 80 с.

Iordanishvili A. K., Moroz P. V. Endodontoparodontal lesions of the chewing apparatus and their treatment: study guide. - SPb.: Izd-vo «Chelovek», 2017. - 80 s.

Siqueira, J. F., Rocas I. N. Community as the unit of pathogenicity: an emerging concept as to the microbial pathogenesis of apical periodontitis // Oral. Surg. Oral. Med. Oral. Pathol. Oral. Radiol. Endod. 2009. Vol. 107. P. 870-878.

Zehnder M., Gold S.I., Hasselgren G. Pathologic interaction in pulpal and periodontal tissues // J. Clin. Periodontol. 2002. Vol. 29. P. 663-671.

Walker M. The pathogenesis and treatment of endo-periolesions // Pathogenesis. 2001. Vol. 2. №3. P. 91-95. 